\title{
Monitoring the acute phase response: comparison of tumour necrosis factor (cachectin) and C-reactive protein responses in inflammatory and infectious diseases
}

\author{
C P J MAURY \\ From the Fourth Department of Medicine, University of Helsinki, Helsinki, Finland
}

SUMMARY The relation between the inflammatory cytokine tumour necrosis factor- $\alpha$ (TNF or cachectin), which induces acute phase responses, and an established acute phase protein, C-reactive protein, was studied in various infectious and inflammatory diseases in man. All cases with very high serum concentrations of C-reactive protein $(150$ to $400 \mathrm{mg} / \mathrm{l}$; normal reference value $<10 \mathrm{mg} / \mathrm{l})$ also had raised serum concentrations of TNF $(53$ to $705 \mathrm{ng} / \mathrm{l}$; normal reference value $<40 \mathrm{ng} / \mathrm{l}$ ). In 19 out of $91(21 \%)$ of the cases, however, a raised TNF concentration without correspondingly raised Creactive protein concentration was also noted. Conversely, in 23 out of $106(22 \%)$ cases raised Creactive protein was observed in the absence of a raised TNF concentration. The ratios were high in allograft rejection and low in myocardial infarction and Kawasaki's disease. The highest mean concentration of circulating TNF was found in bacterial infections, graft rejection, and myocardialo infarction.

It is concluded that although high $\mathrm{C}$-reactive protein concentrations are usually accompanied by raised TNF concentrations, there are pronounced relative variations in the serum concentrations of these proteins in various disease states, suggesting that there may be independent, disease specific regulatory pathways for TNF and C-reactive protein.

Tumour necrosis factor- $\alpha$ (TNF or cachectin) is a hormone-like intercellular signal peptide with a role in host defence processes against tumour cell growth and parasite infection. Recent studies have also implicated TNF in the regulation of normal cell metabolism and as an effector molecule in various processes related to inflammation. ${ }^{12}$ TNF is elaborated mainly by cells of the mononuclear phagocyte system and induces several phenomena associated with the acute phase response such as fever, granulocyte activation, and hepatic protein synthesis. Raised concentrations of circulating TNF in certain inflammatory diseases have recently been reported. ${ }^{3-11}$ To gain insight into the association between circulating TNF and the acute phase response in disease, TNF was measured in various pathological conditions and compared with the concentration of $\mathrm{C}$-reactive protein, and in some instances, also with serum amyloid A protein (SAA), acute phase proteins known to be produced by the liver.

Accepted for publication 25 May 1989

\section{Patients and methods}

Cross sectional studies were carried out in 139 patients with rheumatoid arthritis $(n=22)$, systemic lupus erythematosus $(n=17)$, Kawasaki's disease $(n=39)$, myocardial infarction $(n=10)$, renal allograft rejection $(n=9)$, human immunodeficiency virus (HIV) infection $(n=21)$ or systemic bacterial diseases $(n=$ 21). Serum samples from 40 healthy blood donors served as controls.

Longitudinal studies were carried out in cases of myocardial infarction $(11,15$, and 19 samples, respectively/patient), renal allograft rejection (23 and 24 samples, respectively/patient), Gram negative septicaemia (12 samples/patient), AIDS (six samples/ patient), Crohn's disease (eight samples/patient) and histiocytosis (11 samples/patient).

TNF in serum was measured using a sensitive double antibody radioimmunoassay. ${ }^{12}$ The detection limit of the assay is $7 \mathrm{ng} / \mathrm{l}$. To calculate the intra-assay and interassay coefficients of variation sera were analysed over 26 days in three parallel determinations 1078 
Table 1 Correlation between serum TNF and C-reactive protein concentrations in disease expressed as means (SEM)

\begin{tabular}{|c|c|c|c|c|c|}
\hline Patient group/disease & $(n=)$ & $T N F(n g / l)$ & $\begin{array}{l}\text { C-reactive protein } \\
(\mathrm{mg} / \mathrm{l})\end{array}$ & $\underset{r}{T N F} \vee C R P$ & $\begin{array}{l}T N F: C \text {-reactive } \\
\text { protein relative } \\
\text { ratio }\end{array}$ \\
\hline $\begin{array}{l}\text { Rheumatoid arthritis } \\
\text { Systemic lupus erythematosus } \\
\text { Kawasaki's disease } \\
\text { Myocardial infarction } \\
\text { Renal allograft rejection } \\
\text { Systemic bacterial infections } \\
\text { HIV infection }\end{array}$ & $\begin{array}{r}22 \\
17 \\
39 \\
10 \\
9 \\
21 \\
21\end{array}$ & $\begin{array}{r}104(25) \\
26(27) \\
34(3) \\
129(32) \\
159(34) \\
327(93) \\
74(16)\end{array}$ & $\begin{array}{l}30(7) \\
7(3) \\
47(6) \\
88(23) \\
17(6) \\
94(18) \\
17(6)\end{array}$ & $\begin{array}{r}-0.13 \\
-0.03 \\
0.28 \\
0.61 \\
0.68 \\
0.30 \\
0.53\end{array}$ & $\begin{array}{l}3 \cdot 5 \\
3.6 \\
0 \cdot 7 \\
1.5 \\
9 \cdot 4 \\
3 \cdot 5 \\
4 \cdot 2\end{array}$ \\
\hline
\end{tabular}

in nine separate assays for the interassay assessment, and in 10 to 15 parallel measurements, each in one run, for intra-assay precision. The intra-assay and interassay coefficients of variation were $8.2 \%$ and $9.4 \%$, respectively, for a TNF concentration of $15 \mathrm{ng} / \mathrm{l}$, and $6.3 \%$ and $7.0 \%$, respectively, for a concentration of $92 \mathrm{ng} / \mathrm{l}$. The concentrations of TNF in healthy subjects (40 blood donors) was less than $40 \mathrm{ng} / \mathrm{l}$.

C-reactive protein was measured by radial immunodiffusion using specific antiserum (Orion Diagnostica, Finland) and C-reactive protein reference serum (Behringwerke AG, West Germany) as standard. The $\mathrm{C}$-reactive protein concentration in healthy subjects (40 blood donors) was less than $10 \mathrm{mg} / \mathrm{l}$. SAA was measured by radial immunodiffusion as described before. ${ }^{13}$ Normal reference values of SAA are $<15 \mathrm{mg} / \mathrm{l}^{14}$

Results were expressed as mean \pm standard error of mean, and as ranges. Correlation coefficients (r) were calculated using linear regression analysis.

\section{Results}

Serum TNF concentrations were highest in bacterial infections (327 (93) $\mathrm{ng} / \mathrm{l}$, renal allograft rejection (159 (34) $\mathrm{ng} / \mathrm{l}$ ), and myocardial infarction (129 (32) $\mathrm{ng} / \mathrm{l}$ ). The concentrations of TNF in rheumatoid arthritis (104 (25) ng/l) and in HIV infection (74 (16) ng/l) were moderately raised; the mean TNF concentrations in systemic lupus erythematosus were within the normal reference range (table 1). A tendency towards a

Table 2 Correlation between serum TNF and C-reactive protein concentrations in individual patients during follow up

\begin{tabular}{|c|c|c|c|}
\hline \multirow{2}{*}{$\frac{\text { Disease }}{\text { Myocardial infarction }}$} & \multicolumn{2}{|c|}{$\begin{array}{l}\text { Number of } \\
\text { samples }\end{array}$} & $\begin{array}{l}T N F \mathrm{v} \\
C \text {-reactive } \\
\text { protein } r\end{array}$ \\
\hline & $\begin{array}{l}19 \\
15 \\
11\end{array}$ & $\begin{array}{l}\text { (case 1) } \\
\text { (case 2) } \\
\text { (case 3) }\end{array}$ & $\begin{array}{l}0.31 \\
0.63 \\
0.75\end{array}$ \\
\hline Renal allograft rejection & $\begin{array}{l}24 \\
23\end{array}$ & $\begin{array}{l}\text { (case 1) } \\
\text { (case 2) }\end{array}$ & $\begin{array}{l}0.48 \\
0.45\end{array}$ \\
\hline $\begin{array}{l}\text { Septicaemia } \\
\text { Crohn's disease } \\
\text { Histiocytosis } \\
\text { AIDS }\end{array}$ & $\begin{array}{r}12 \\
8 \\
11 \\
6\end{array}$ & & $\begin{array}{r}0.59 \\
-0.13 \\
-0.23 \\
0.33\end{array}$ \\
\hline
\end{tabular}

positive correlation between TNF and C-reactive protein concentrations was seen in both cross sectional (table 1) and longitudinal (table 2) studies of patients with renal allograft rejection (fig 1), myocardial infarction (figs 2 and 3) and in infections: no such correlation was found in rheumatic diseases (table 1). The TNF:CRP ratios were low in myocardial infarction and Kawasaki's disease and high in renal allograft rejection (table 1). Normal TNF concentrations were seen in most cases accompanied by normal C-reactive protein concentrations. In 23 of $106(22 \%)$ cases, however, raised $\mathrm{C}$-reactive protein concentration $(>10 \mathrm{mg} / \mathrm{l})$ was found in the absence of raised TNF. Conversely, in 19 of $91(21 \%)$ cases a raised TNF concentration was noted, in spite of a normal Creactive protein concentration. In all cases with a very high C-reactive protein concentration (range 150 to $400 \mathrm{mg} / \mathrm{l}$ ) a raised TNF concentration was also found (range 53 to $705 \mathrm{ng} / \mathrm{l}$ ).

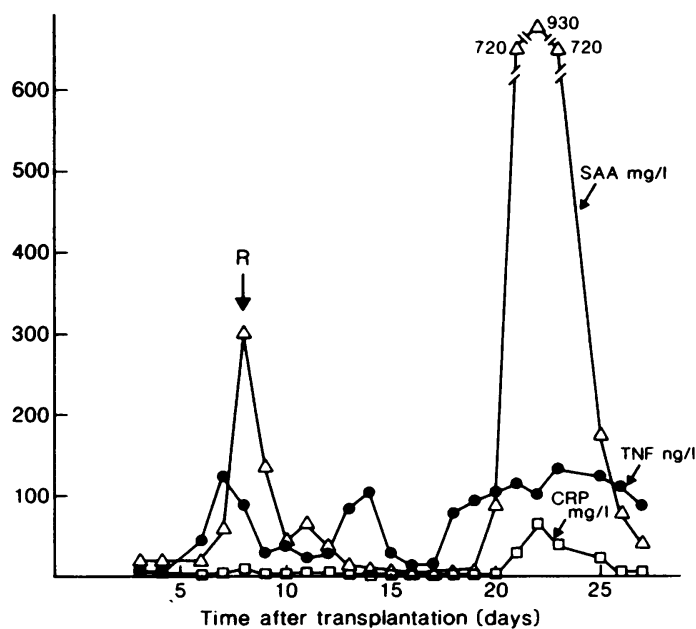

Fig 1 Correlation between TNF (O-O), C-reactive protein $(\square-\square)$, and $S A A(\triangle-\triangle)$ responses in a 30 year old man following cadaveric renal transplantation and immunosuppressive treatment with azathioprine and cyclosporine. The acute phase reaction peaking on the 22nd day after transplantation was associated with a fever episode of unknown aetiology. $R$ indicates a graft rejection episode. 


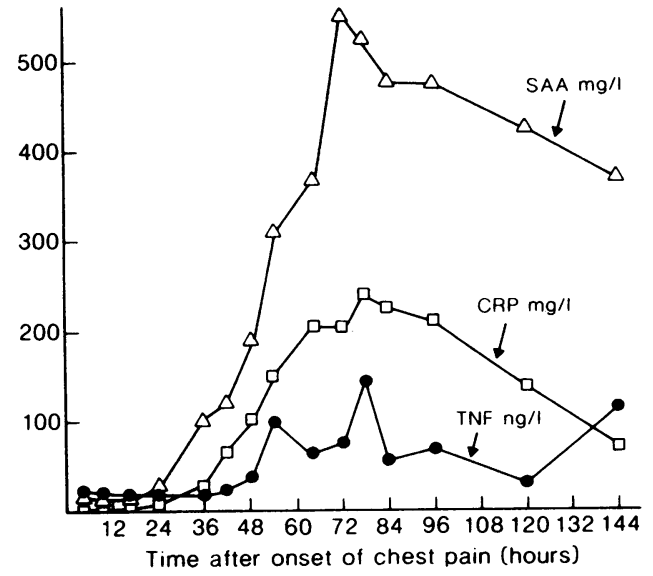

Fig 2 Correlation between serum $T N F(-0), C$-reactive protein ( $\square-\square)$, and $S A A(\triangle-\triangle)$ in a 66 year old man who had had an acute, large, inferoapical transmural myocardial infarction. He died seven days after the onset of chest pain.

\section{Discussion}

TNF is an inflammatory cytokine implicated in the pathogenesis of several conditions including septic shock, ${ }^{415}$ cachexia, ${ }^{1617}$ graft rejection, ${ }^{5}$ graft versus host disease,$^{18}$ cerebral malaria ${ }^{19}$ vasculitis in Kawasaki's disease ${ }^{20}$ and haematological abnormalities in inflammatory diseases. ${ }^{21}$ Raised concentrations of circulating TNF have recently been reported in various infectious, inflammatory, and malignant diseases. ${ }^{3-12}$ Most of these represent states also characterised by an acute phase reaction and increased $\mathrm{C}$ reactive protein concentrations. As TNF is known to induce acute phase protein synthesis in the liver, ${ }^{22}{ }^{23}$ the question arises whether a raised TNF concentration has the same clinical implications as a raised $C$ reactive protein concentration and what the association between the concentrations of these proteins in the circulation in various diseases is.

Analysis of the data showed that, irrespective of the underlying disease, very high $\mathrm{C}$-reactive protein concentrations $(\geq 150 \mathrm{mg} / \mathrm{l})$ were always associated with increased circulating concentrations of TNF. There were, however, noticeable disease dependent variations of TNF concentrations and the correlation between high $\mathrm{C}$-reactive protein concentrations and corresponding TNF concentrations was weak. This finding was also reflected in the pronounced variation in the relative TNF $C$-reactive protein ratios in disease. The ratio was high in immunological tissue injury (renal allograft rejection)-high TNF and low C-reactive protein responses. In contrast, tissue injury in association with myocardial infarction was characterised by low TNF: C-reactive protein ratios.

In $21 \%$ of the cases raised TNF concentrations was observed in the absence of an increased C-reactive protein concentration; most of these cases were associated with immunological tissue injury. Conversely, in $22 \%$ a raised $\mathrm{C}$-reactive protein concentration was found in the absence of raised TNF; these occurred in different diseases including bacterial infections and rheumatoid arthritis.

Our results show that the TNF response in inflammation is disease specific and differs in several respects from the C-reactive protein response. Activation of monocytes and macrophages, ${ }^{12}$ and possibly other cells as well, ${ }^{24}$ is the primary event which initiates TNF production. Experimental studies show that a wide range of infectious and non-infectious agents can activate mononuclear phagocytes. Interestingly, the gene coding for TNF has been mapped to chromosome 6 in close linkage to the major histocompatibility genes. ${ }^{25}$ The finding of abnormal TNF expression in conditions characterised by dysfunction of the regulation of the immune system is not, therefore, surprising.

TNF induces the synthesis of hepatic acute phase proteins by modulating gene expression during the acute phase response. TNF, however, is not the only humoral factor involved. Interleukin $1^{26}$ and interleukin $6^{232728}$ also induce acute phase protein synthesis. The relative roles and possible interaction of the various cytokines in inducing $\mathrm{C}$-reactive protein synthesis in man is not known, but the pronounced differences in $\mathrm{C}$-reactive protein responses at certain

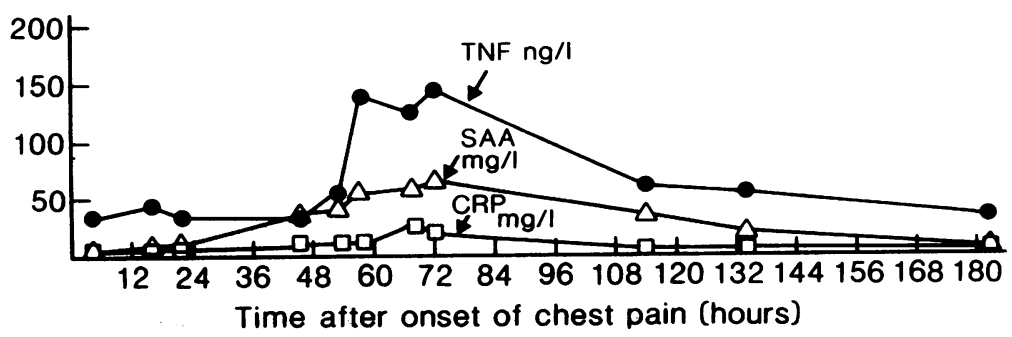

Fig 3 Correlation between serum TNF (O-O), C-reactive protein ( $\square-\square)$, and $S A A$ $(\triangle-\triangle)$ in an 84 year old man with a non fatal anteriolateral myocardial infarction.

Note the lesser acute phase protein response in this patient than in the patient shown in fig 2 , although both patients had similar TNF response curves. 
TNF concentrations suggest that mediators other than TNF may also be implicated.

The different TNF:CRP ratios resulting from various acute inflammatory stimuli may also be explained by differences in consumption and clearance from the circulation. Anti-inflammatory and immunosuppressive drugs may also affect the metabolism of TNF and C-reactive protein differently. Using a bioassay for serum TNF, Waage et al have calculated that the half-life of TNF is about 70 minutes in patients with meningococcal septic shock. ${ }^{29}$ In cancer patients receiving intravenous recombinant TNF, the half-life in blood was estimated at 20 minutes. ${ }^{30}$ Data from studies on mice ${ }^{31}$ and rats ${ }^{32}$ show a great variation of the measured half-lives of SAA, depending probably both on experimental design and species difference. The in vivo half-life of labelled $\mathrm{C}$-reactive protein in the circulation of rabbits has been reported to be four to six hours. ${ }^{33}$ In man serial measurements of the serum concentrations of SAA and C-reactive protein following tissue injury ${ }^{34}$ and ethiocholanolone administration, ${ }^{35}$ however, show that the kinetics of these proteins are similar. Our results show that the kinetics of the TNF and SAA and C-reactive protein responses following tissue injury are also rather similar, though the correlation between TNF and Creactive protein is considerably weaker than the correlation between C-reactive protein and SAA under these conditions.

The technical assistance of A-M Teppo in the TNF assays is gratefully acknowledged.

This study was supported by the Sigrid Jusélius Foundation, the Swedish Cultural Foundation, and the Cancer Foundation, Finland.

\section{References}

1 Maury CPJ. Tumour necrosis factor- $\alpha$. An overview. Acta Med Scand 1986;220:387-94.

2 Le J, Vilcek J. Tumor necrosis factor and interleukin 1: cytokines with multiple overlapping biological activities. Lab Invest 1987;56:234-48.

3 Scuderi P, Lam KS, Ryan KJ, et al. Raised serum levels of tumour necrosis factor in parasitic infections. Lancet 1986;ii:1364-5.

4 Waage A, Halstensen A, Espevik T. Association between tumour necrosis factor in serum and fatal outcome in patients with meningococcal disease. Lancet 1987; i:355-7.

5 Maury CPJ, Teppo A-M. Raised serum levels of cachectin tumor necrosis factor- $\alpha$ in renal allograft rejection. $J$ Exp Med 1987;166:1132-7.

6 Blakwill F, Osborne R, Burke F. Evidence for tumour necrosis factor/cachectin production in cancer. Lancet 1987;ii:1229-32.

7 Lähdevirta J, Maury CPJ, Teppo A-M, Repo H. Elevated levels of circulating cachectin/tumor necrosis factor in patients with acquired immunodeficiency syndrome. Am J Med 1988;85: 289-91.

8 Maury CPJ, Teppo A-M. Tumor necrosis factor in the serum of patients with systemic lupus erythematosus. Arthritis Rheum 1989;32:146-50.

9 Maury CPJ, Pettersson T. Detection of circulating tumour necrosis factor in systemic histiocytosis. $\mathrm{Br} J$ Haematol 1989;71:293-5.

10 Maury CPJ, Teppo A-M, Salo E, Pelkonen P. Detection of circulating tumor necrosis factor in Kawasaki disease: pathogenetic implications. J Lab Clin Med 1989;113:651-4.

11 Maury CPJ, Teppo A-M. Circulating tumour necrosis factor- $\alpha$ (cachectin) in myocardial infarction. J Intern Med 1989;225: 333-6.

12 Teppo A-M, Maury CPJ. Radioimmunoassay of tumor necrosis factor in serum. Clin Chem 1987;33:2024-7.

13 Maury CPJ, Teppo A-M. Comparative study of serum amyloidrelated protein and $\beta$-2-microglobulin as markers of renal allograft rejection. Clin Nephrol 1984;22:284-92.

14 Maury CPJ, Teppo A-M, Salaspuro MP. Amyloid A fibril degrading activity in serum in liver disease: relation to serum acute phase and other protein levels. Clin Chim Acta 1983;131:29-37.

15 Tracey KJ, Fong Y, Hesse DG, et al. Anti-cachectin/TNF monoclonal antibodies prevent septic shock during lethal bacteraemia. Nature 1987;330:662-4.

16 Price SR, Olivercrona T, Pekala PH. Regulation of lipoprotein lipase synthesis by recombinant tumor necrosis factor-the primary regulatory role of the hormone in $3 \mathrm{~T} 3-\mathrm{L}, 1$ adipocytes. Arch Biochem Biophys 1986;251:738-42.

17 Tracey KJ, Wei H, Manogue KR, et al. Cachectin/tumor necrosis factor induces cachexia, anemia, and inflammation. J Exp Med 1988;167:1211-27.

18 Piguet P-F, Grau GE, Allet B, Vassalli P. Tumor necrosis factor/ cachectin is an effector of skin and gut lesions of the acute phase of graft-vs.-host disease. J Exp Med 1987;166:1280-9.

19 Grau GE, Fajardo LF, Piguet P-F, Allet B, Lambert P-H, Vassalli P. Tumor necrosis factor (cachectin) as an essential mediator in murine cerebral malaria. Science 1987;237:1210-12.

20 Leung DYM, Geha RS, Newburger JW, et al. Two monokines, interleukin 1 and tumor necrosis factor, render cultured vascular endothelial cells susceptible to lysis by antibodies circulating during Kawasaki syndrome. $J$ Exp Med 1986;164:1958-72.

21 Maury CPJ, Juvonen E, Lähdevirta J, Andersson LC. Mechanism of anaemia and cachexia in chronic inflammatory disease: role of cytokines. Int J Tiss React (In press).

22 Perlmutter DH, Dinarello CA, Punsel PI, Colten HR. Cachectin/ tumor necrosis factor regulates hepatic acute-phase gene expression. J Clin Invest 1986;78:1349-54.

23 Ramadori G, Van Damme J, Rieder H, Meyer zum Büschenfeld $\mathrm{K}-\mathrm{H}$. Interleukin 6, the third mediator of acute phase reaction, modulates hepatic protein synthesis in human and mouse. Comparison with interleukin $1 \beta$ and tumor necrosis factor $\alpha$. Eur J Immunol 1988;18:1259-64.

24 Sung S-SJ, Jung LKL, Walters JA, Chen W, Wang CY, Fu SM. Production of tumor necrosis factor/cachectin by human $B$ cell lines and tonsillar B cells. J Exp Med 1988;168:1539-51.

25 Spies T, Morton CC, Nedospasov SA, Fiers W, Pious D, Strominger JL. Genes for the tumor necrosis factors alpha and beta are linked to the human major histocompatibility complex. Proc Natl Acad Sci USA 1986;83:8699-702.

26 Ramadori G, Sipe JD, Dinarello CA, Mizel SB, Colten HR. Pretranslational modulation of acute phase hepatic protein synthesis by murine recombinant interleukin 1 (IL-1) and purified human IL-1.J Exp Med 1985;162:930-42.

27 Baumann H, Hill RE, Sander DN, Jahries GP. Regulation of major acute-phase proteins by hepatocyte-stimulating factors of human squamous carcinoma cells. J Cell Biol 1986;102: 370-83.

28 Castell JV, Gómez-Lechón MJ, David M, Hirano T, Kishimoto T, Heinrich PC. Recombinant human interleukin-6 (IL-6/BSF-2/ HSF) regulates the synthesis of acute phase proteins in human hepatocytes. FEBS lett 1988;232:347-50.

29 Waage A, Brandtzaeg P, Halstensen A, Kierulf P, Espevik T. The complex pattern of cytokines in serum from patients with 
meningococcal septic shock. Association between interleukin 6, interleukin 1 and fatal outcome. J Exp Med 1989;169:333-8.

30 Chapman PB, Lester TJ, Casper ES, et al. Clinical pharmacology of recombinant human tumor necrosis factor in patients with advanced cancer. J Clin Oncol 1987;5:1942-51.

31 Hoffman JS, Benditt EP. Plasma clearance kinetics of the amyloidrelated high density lipoprotein apoprotein, serum amyloid protein (apoSAA) in the mouse: evidence for rapid SAA clearance. J Clin Invest 1983;71:926-34.

32 Enholm C, Teppo A-M, Ohisalo JJ, Maury CPJ. Human highdensity lipoprotein associated amyloid A protein. Structural characteristics, relation to apoA-I and A-II concentrations, and plasma clearance kinetics in the rat. Scand $J$ Rheumatol 1985;14:201-8.

33 Chelladurai M, Macintyre SS, Kushner I. Estimation of in vivo rates of C-reactive protein synthesis from serum turnover studies in rabbits. Ann NY Acad Sci 1982;389:437-8.

34 Maury CPJ, Teppo A-M, Raunio P. Control of the acute phase serum amyloid $\mathbf{A}$ and $\mathbf{C}$-reactive protein response. Comparison of total replacement of the hip and knee. Eur J Clin Invest 1984;14:323-8.

35 McAdam KPWJ, Elin FR, Sipe JD, Wolff SM. Changes in human serum amyloid $A$ and $C$-reactive protein after etiocholanolone induced inflammation. J Clin Invest 1978;61:390-4.

Requests for reprints to: Dr C P J Maury, Senior Lecturer in Medicine, Fourth Department of Medicine, University of Helsinki, Unioninkatu 38, SF-00170 Helsinki, Finland. 